\title{
Transformation of Conflict Governance in Forest Management Unit Jeneberang II
}

\author{
Ulfiah Nurhikmah1, Yusran Jusuf ${ }^{2}$ \\ ${ }^{1}$ Forestry Study Program, Graduate School Hasanuddin University, Makassar, 90245, Indonesia \\ ${ }^{2}$ Forestry Study Program, Graduate School Hasanuddin University, Makassar, 90245, Indonesia
}

Correspondence Author: Ulfiah Nurhikmah, Forestry Study Program, Graduate School Hasanuddin University, Makassar, 90245

Email: ulfiahnurhikmah@pasca.unhas.ac.id

Received date: 29 August 2019, Accepted date: 22 October 2019, Online date: 30 October 2019

Copyright: (c) 2019 Ulfiah Nurhikmah and, Yusran Jusuf. This is an open-access article distributed under the terms of the Creative Commons Attribution License, which permits unrestricted use, distribution, and reproduction in any medium, provided the original author and source are credited.

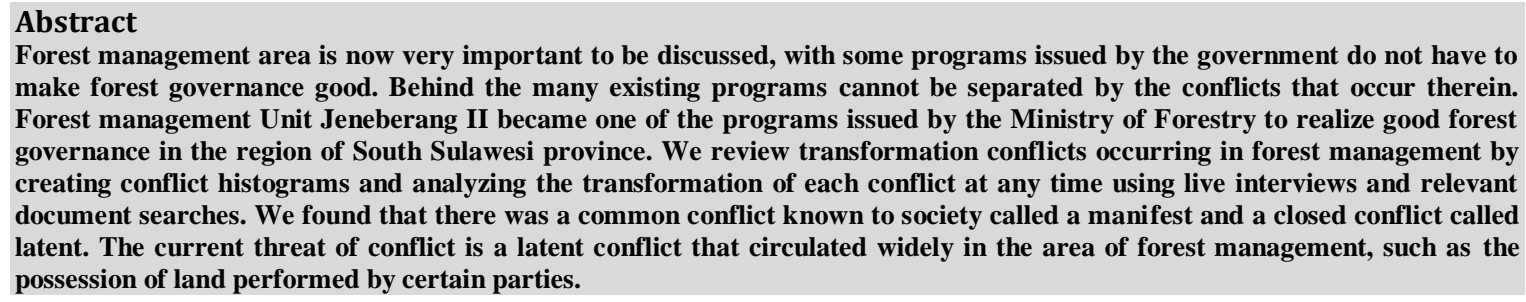
make forest governance good. Behind the many existing programs cannot be separated by the conflicts that occur therein. Forest management Unit Jeneberang II became one of the programs issued by the Ministry of Forestry to realize good forest governance in the region of South Sulawesi province. We review transformation conflicts occurring in forest management by creating conflict histograms and analyzing the transformation of each conflict at any time using live interviews and relevant document searches. We found that there was a common conflict known to society called a manifest and a closed conflict called latent. The current threat of conflict is a latent conflict that circulated widely in the area of forest management, such as the possession of land performed by certain parties.

Keywords: Transformation, Conflict, Latent, Manifest

\section{INTRODUCTION}

Forest management Unit is one of the Forestry Ministry programs in realizing good forestry governance. Forest management becomes the base of forest management at the site level which is expected to manage and control the management of the forest responsibly. Forest management Unit Jeneberang II South Sulawesi Province which is located in three districts namely Sinjai, Bulukumba, and Bataeng also suffered heavy pressure of many claims from local communities of land ownership in forest areas and the need for Utilization of forest resources. One fact that can not be denied is that the management of forests in Indonesia is still coloured in various conflicts. The absence of justice in forest management impacts the spread of conflicts in forest areas [1]. An estimated 130 million ha of forests are now a conflict arena due to overlapping land of state Forest claims and claims of indigenous peoples or other local communities, as well as some other sectors that even claim forest areas. The biggest conflict occurs because of overlapping of land tenure and utilization[2] . Forestry development until now has not been fully concerned with the reality of community rights, utilization and possession of land field[3]and[4] . Behind that, the government has been issued a lot of policies to expand the access of the community with the social forestry program that is currently being lively talked about by the community. In addition, the uncertainty of forest areas in this region is a barrier to forest governance. This uncertainty triggered the emergence of land conflicts with various stakeholders with forest areas.

In the view of conflict transformation, conflict is something normal and always exists in human social relations. A Conflict transformation initiative aimed at knowing the position of conflict and how it changes over time. Each conflict transformation initiative will have an implicit or explicit impact, the theory of how it will bring about change in conflict [5]and[6]

This problem makes us think that this research should be to make a transformation of conflict governance in the management of conflict in the Forest Management Unit Jeneberang II to review the extent to which conflicts are transformed year by year.

\section{METHODS}

This research uses the analysis of conflict dimensions using conflict histogram obtained by the method of interviewing and document tracing in conflict transformation studies [7].

In identifying existing conflicts, the assessed parameters are those in conflict, what causes the conflict, why conflicts can occur, where they conflict, when conflicts occur, and how they are transformational. Meanwhile, to illustrate the conflict histogram and 
analyze the transformation of forest management conflicts at Forest management Unit Jeneberang II, used the same approach with [8] which describes the three dimensions of conflict:

1. Definition/Conflict substance

2. Settlement/Regulation

3. Empirical state

Therefore, the conflict is said to be Latent when a conflict exists in a conflict substance but does not appear in empirical state, whereas the conflict is said to Manifest when conflicts exist in the conflicting substance and appear in empirical state, so Conflicts will only be said to Manifest when there is an empirical in the conflict.

\section{RESULT AND DISCUSSION}

\section{Identification of conflicts and actors and their interests}

Land conflicts in Forest management Unit Jeneberang II began to occur in the 1990s that are within the boundary of Forest management Unit Jeneberang II forest area of $\pm 30,216$ ha.

This resulted in all the areas of residential and community governance included in the area of Forest management Unit Jeneberang II, where the land owned by the community already existed before. This conflict finally peaked in from 2006 to 2010 in the area of Forest management Unit Jeneberang II.

Broadly, the conflicts of interest that occurred in the management of Forest management Unit Jeneberang II is; (1) Conflicts due to the clear boundary of forest areas in some areas of Forest management Unit Jeneberang II, (2) Tax payable Notice conflict is never resolved, (3) Forest boundary conflicts limit the area of the District, (4) Land enforcement at Forest Park area Bonto Bahari District Bulukumba (5) conflict due to a land rehabilitation program damaged by the local community, (6) Conflict due to the existence of Forest Park area land sold by the person, (7) conflicts due to the mastery of the community and the local civil apparatus. To explain the journey from conflict (the conflict histogram) can be seen below in :

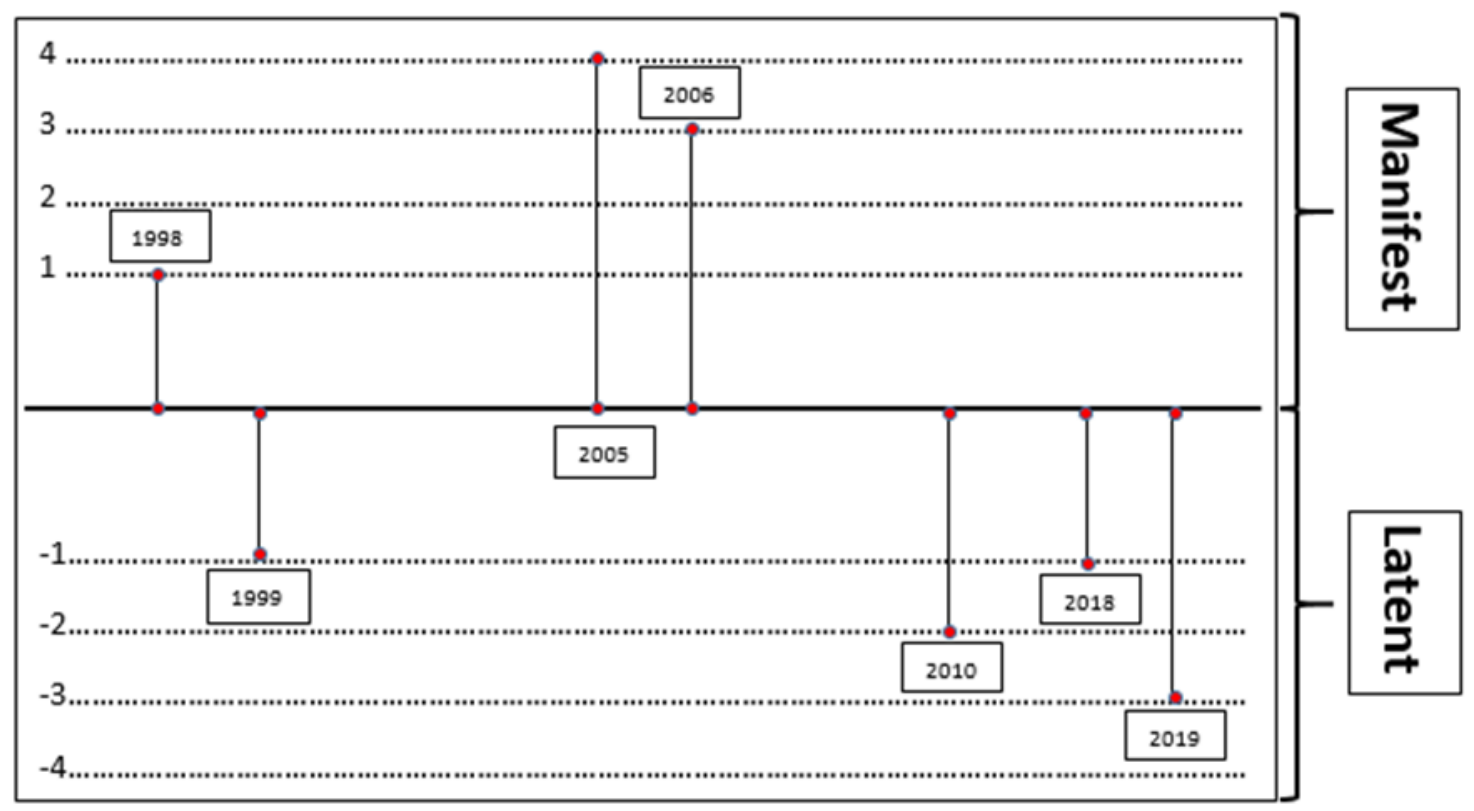

Table 1. Conflict Histogram Description

\begin{tabular}{|c|c|c|c|c|}
\hline No. & Model & Points & Conflict entity & Year \\
\hline 1 & $1-0-1$ & 1 & Conflict due to the clear boundary of forest area in some areas of Forest management Unit & 1998 \\
\hline 2 & $1-1-0$ & -1 & Uneberang II & 1999 \\
\hline 3 & $1-1-1$ & 4 & Forest boundary conflicts are restricted by district area that does not lead to an agreement & 2005 \\
\hline 4 & $1-1-1$ & 3 & Land enforcement at Forest Park area Bonto Bahari Bulukumba District & 2006 \\
\hline 5 & $1-1-0$ & -2 & Conflict due to land rehabilitation programmes damaged by local communities & 2010 \\
\hline 6 & $1-1-0$ & -1 & Conflict due to the existence of Forest Park area land sold by the person & 2018 \\
\hline 7 & $1-0-0$ & -3 & Conflicts due to the mastery of community and local civil apparatus & 2019 \\
\hline
\end{tabular}

Of the 7 conflicts above, there are people or groups who have an interest in resources and have a major influence on the conflicts. These people or groups are referred to as conflicting actors [9][10]. Actors involved and have a major influence on the conflict in the management of Forest management Unit Jeneberang II as follows: 


\section{Forestry Service}

The forestry service became a working group related to the policy issued by the administration of Forest management Unit Jeneberang II, because the program carried out by forest management was followed up by the forestry service.

\section{Government agencies}

Government agencies from the district level, the subdistrict to the village greatly influence the importance of the management of conflicts that occurred in the Forest Management Unit Jeneberang II to the benefit of both administration and support.

\section{The community}

The community within Bulukumba, Bantaeng, and Sinjai counties gave the interest to access to the land area of Forest management Unit Jeneberang II. Access in the form of residence and land for plantation activities.

\section{Ministry of Forestry}

The importance of the Ministry of Forestry (central government) is to preserve the area of existing forest areas. Although indirectly involved in the conflict, the Ministry of Forestry has a major influence on existing policies because it is the highest decision maker in forest management.

\section{Non-governmental organizations}

NGO's interests are to help people to fight their rights. The rights referred to in this case are the land areas of the community claimed by the government.

\section{Forest Park Manager}

The Forest Park is one of the influential parties that is quite large because of the many people who are currently arguing about the existence of public land that has been claimed into the Forest Park area.

\section{Analysis of conflict transformation in Forest Management Unit Jeneberang II}

The transformation of conflicts occurring in the Forest management Unit Jeneberang II is detailed as follows:

1) Conflict due to the clear boundary of forest area in some areas of Forest management Unit Jeneberang II

Conflicts due to the clear boundaries of the region become a major problem at this time, based on the results of interviews with the community said that in 1998 at the end of Suharto reign was claimed forest areas contrary to the results Claims made by the public from the previous year.

\section{2) Unresolved Tax payable Notice conflict}

The next conflict is the problem of Tax payable Notice owned by the community and the social gap because it does not, in fact, the publication of this Tax payable Notice. Interviews conducted by government agencies and communities say that the number of people complaining about Tax payable Notice issues that cannot be published.

\section{3) Forest boundary conflicts are restricted by district area that does not lead to an agreement}

Forest boundary conflicts are restricted by the districts of Bantaeng - Bulukumba and Bulukumba District - Sinjai. In this region, there are several forest areas that claim the two districts started in 2005 and until now the absence of decisions and agreements

\section{4) Land enforcement at Tahura Bonto Bahari Bulukumba District}

Land-enforcement conflicts in the area of Bonto Bahari Forest Park began in 2006 when Forest Park began to be known by many people and the number of people who began to enter this area for tourism.

\section{5) Conflict due to land rehabilitation programmes damaged by local communities}

The conflict was due to a land rehabilitation program in 2010 to date damaged by local people for various reasons.

\section{6) Conflict due to the existence of Forest Park area land sold by the person}

The conflict of land of the forest park sold as much as 25 ha, the conflict began in 2018 and is still a major problem.

\section{7) Conflicts due to the mastery of community and local civil apparatus}

The conflict of mastery conducted by the community and civil apparatus of the state in the village Wood Lohe, District Bantaeng, Kab. Bantaeng began in May 2019 and until now is still unresolved.

\section{CONCLUSION}

Conflict transformation in Forest management Unit Jeneberang II began in 1998 to date and corresponds to the conflict entity that occurs there are two different manifest and latent conflicts detailed as follows: (a) manifest conflicts such as Conflict due to 
the clear boundary of forest area in some areas of Forest management Unit Jeneberang II, Forest boundary conflicts are restricted by district area that does not lead to an agreement, Land enforcement at Forest Park area Bonto Bahari Bulukumba District, Land enforcement at Forest Park area Bonto Bahari Bulukumba District (b) Latent conflicts such as Unresolved Tax payable

Notice conflict, Conflict due to land rehabilitation programmes damaged by local communities, Conflict due to the existence of

Forest Park area land sold by the person, Conflicts due to the mastery of community and local civil apparatus.

\section{REFERENCE}

[1] Frazer, Owen. 2013. Conflict Transformation in Practice. Cordoba Now Forum : ETH Zurich

[2] Husein, I.A. 2015. Legal Protection of State Forest Areas Against Criminal Acts on Forest Destruction (Study case in KPH Nganjuk Unit II Jawa Timur). Brawijaya University. Malang (ID)

[3] Hendrix, C. S. (2010). Measuring state capacity: Theoretical and empirical implications for the study of civil conflict. Journal of Peace Research, 47(3), 273-285. https://doi.org/10.1177/0022343310361838

[4] Pernando Sinabutar, Bramasto Nugroho, Hariadi Kartodihardjo, Dudung Darusman. 2015. Legal Certainty and Recognition of the Parties as a Result of the Establishment of State Forest Areas in Riau Province. Journal of Forestry Policy Analysis Vol. 12 No. 1, April $2015: 27-40$.

[5] Hasanuddin, Dr. 2011. Local Wisdom and Mediation of Conflict Transformation in West Sumatra. Padang (ID) : Andalas University National Resilience Study Center

[6] S Langputeh, D Fitraini - 2017. Implementation of Peace Education in the Context of Conflict Transformation in Southern Thailand. (Accessed May 8, 2019 http://repository.uin-suska.ac.idFrazer, Owen. 2013. Conflict Transformation in Practice. Cordoba Now Forum : ETH Zurich

[7] Deshmukh, A. (2011). The Alchemist: Analysis of Major Characters. Indian Streams Research Journal, 1-7 vol L.

[8] Yusran, Y., M. A. K. Sahide., S. Supratman., A. Sabar., M. Krott dan L. Giessen. 2017. The Empirical Visibility of Land Use Conflicts; From Latent to Manifest Conflict Through Law Enforcement in a National Park in Indonesia. Land Use Policy, 62 (2017), 302-315.

[9] Nurhapsa,Kusnadi,N., Firdaus, M., Sirajuddin,S.N .2014. Actors affecting farmer's productivity new potato yield varieties. American-Eurasian Journal of Sustainable Agriculture. AENSI. 5(1).

[10] Alvian, L. dan E.Y. Suryandari. 2008. Study on Forest Management Unit Model of Forest Way Register Model 47. Bogor (ID) 